\title{
The missing continent
}

Ten years ago, in ET5 (Jan 86), we published a letter from M. J. Nash in London entitled 'the Argentine connection', in which he wrote: 'I would welcome an article on English as spoken by the largest British community outside the Commonwealth, a million strong in Argentina. It's about time that this community be properly studied.' I agreed with him then and still do, but was never able to find anyone qualified and willing to write the article.

Much more recently, in ET47 (Jul 96), in the editorial 'Continental Englishes', I reflected on how English has become the pre-eminent second language of the middle-classes (older and newer) in South and East Asia, and increasingly of the movers and shakers of the European Union and neighbouring countries. This journal has also in various ways recognised the dominance of the language in North America and Australasia/Oceania as well as its vigour and variety across Africa, but throughout twelve years of publication as the international review of the language we have been virtually silent on South America.

With the last issue (ET48, Oct 96) things began to change, when we published Herman Wekker's article on the English creoles of Surinam (former Dutch Guiana). And in this issue there is a significant further breakthrough with Annick Mompean's 'Pronouncing English in Brazil' and Graciela Moyano's 'English in Argentina'.

Something else to observe these days in South America is Mercosur ('southern market'), an incipient common market formed by Brazil, Paraguay, Uruguay, and Argentina. Traditionally, Portuguese-speaking Brazilians have been set apart from the Spanish-speaking states of the southern American continent. Now, however, Spanish and Portuguese are coming more into contact through Mercosur, but even so interest in English in all the Mercosur countries may make it a handy - and neutral link between speakers of these neighbouring and historicallyrelated but hardly identical languages, as it often is among Germanic-speaking peoples in northern Europe.

With our reports from the largest countries in South America ET's coverage has been greatly extended. I look forward now to more not only from Latin America at large but also from Eastern Europe, Central Asia, and Arabic Asia.

Tom McArthur

The editorial policy of English Today is to provide a focus or forum for all sorts of news and opinion from around the world. The points of view of individual writers are as a consequence their own, and do not reflect the opinion of the editorial board. In addition, wherever feasible, ET generally leaves unchanged the orthography (normally British or American) and the usage of individual contributors, although the editorial style of the journal itself is that of Cambridge University Press.

(c) Cambridge University Press 1997. No contents may be reproduced by any means without the permission of Cambridge University Press.

English Today (ISSN 0266-0784) is a quarterly.

\section{Publisher:}

Cambridge University Press,

The Edinburgh Building, Cambridge

CB2 2RU, United Kingdom.

Telephone (01223) 312393 Email:

English_Today@cup.cam.ac.uk

Subscriptions: the current annual subscription price for four issues for libraries and institutions is $£ 53$ outside North America; $£ 27$ for individuals; $£ 21$ for students and the retired. Prices include delivery by air where appropriate. Apply to Jane Crossland at the above address.

Advertising Sales: write to the Advertising Promoter at the above address.

USA, CANADA AND MEXICO:

\section{Publisher:}

Cambridge University Press, 40 West 20th Street, New York, NY 10011-4211, USA.

Telephone (212) 9243900.

Subscriptions: the current annual subscription price in USA, Canada and Mexico for libraries and institutions is $\$ 85$; $\$ 43$ for individuals; $\$ 32$ for students and the retired. Apply to Joseph D. Hranek at the above address.

Advertising Sales: write to the Advertising Coordinator at the above address.

Periodicals postage paid at New York, NY and at additional mailing offices.

POSTMASTER: send address changes in USA, Canada and Mexico to English Today, Cambridge University Press, 110 Midland Avenue, Port Chester, New York, NY 10573-4930, USA.

Japanese prices for institutions are available from Kinokuniya Company Ltd, P.O. Box 55, Chitose, Tokyo 156, Japan.

Letters to the Editor: write to $\mathrm{Dr}$ Tom McArthur, Editor, English Today, 22-23 Ventress Farm Court, Cherry Hinton Road, Cambridge CB1 4HD, UK. Tel 01223245934 , Fax 01223241161 . Email: tmca@scotsway.demon.co.uk

Information on English Today and all other Cambridge journals can be accessed via

http://www.cup.cam.ac.uk/ and in North America via http://www.cup.org/.

Printed in the United Kingdom by the University Press, Cambridge 